\title{
EFFECT OF DIFFERENT LEVELS OF TRYPTOPHAN SUPPLEMENTATION ON GROWTH PERFORMANCE AND SOME BLOOD CONSTITUENTS OF SINAI BEDOUIN CHICKS
}

\author{
M. E. Soltan and Eman A. Hussein \\ Poult. Prod. Dept, Fac. of Agric., Menoufia Univ., Shebin El-Kom, Egypt.
}

(Received 9/10/2017, accepted 20/11/2017)

\section{SUMMARY}

\begin{abstract}
A total of one hundred and twenty, unsexed Sinai Bedouin chicks, one day old were used in this experiment. Chicks were allocated to four dietary treatments of thirty chicks which included three replicates of ten chicks. The experiment lasted for 16 weeks. Growth performance parameters, some blood parameters and economical efficiency were determined. The first group $\left(\mathrm{T}_{1}\right.$, control basal diet content normal level of tryptophan supplementation, $\mathrm{T}_{2}, \mathrm{~T}_{3}$ and $\mathrm{T}_{4}$ contented the supplementation of tryptophan at the levels of $0.20,0.25$ and $0.30 \%$, respectively. Results were indicated that body weight and body weight gain were significantly $(\mathrm{P} \leq 0.05)$ increased by increasing of tryptophan level. The best of feed conversion ratio was recorded for treatment four supplied with $0.30 \%$ tryptophan compared with other treatments. Chicks fed diet supplemented with tryptophan were significantly increased in plasma glucose, Total protein and globulin concentration. No significant differences were noted in transaminase enzymes (ALT and AST) plasma blood concentration between all treatments. Significant decrease was observed in plasma total lipids and total cholesterol with adding tryptophan levels $(0.20,0.25$ and $0.30 \%)$ compared with the basal diets. Tryptophan supplementation at levels $(0.20,0.25$ and $0.30 \%)$ to chick's diet improved economical efficiency. In conclusion, supplementing tryptophan to Beduin Sinai chick's (during growth period) diet had a positive effect on growth performance and some blood constituents, especially addition $0.30 \%$ tryptophan could be recommended for improving Sinai Bedouin chick's health and economic efficiency.
\end{abstract}

Keywords: tryptophan, performance, blood constituents, Sinai Bedouin chicks.

\section{INTRODUCTION}

With progress in biotechnology, the cost of production of each amino acid has been significantly reduced, which has been one of the key factors in the expansion of use of amino acids in animal feed. Amino acids for feed now play very important roles in improving the efficiency of protein utilization in animal feeding Toride (2004). Proteins are made up of amino acids; these amino acids are generally referred to as the building blocks of proteins. They are about 20 comprising of 10 essentials and 10 nonessentials. The essential ones cannot be synthesized enough by the body, hence the need for them to be supplied in the diet, while the non-essential ones can be synthesized enough by the body Esonu (2006). One of the essential amino acids is tryptophan; others are arginine, histidine, leucine, isoleucine, lysine, methionine, phenylalanine, threonine and valine. Among others, tryptophan is often referred to as critical, as it is often difficult to supply in proper amount in feed protein (Oluyemi and Roberts (2007).

Tryptophan (Trp) is essential amino acids that must be obtained from diet. For all amino acids, including L-tryptophan, only the L isomer is used in protein synthesis and can pass across the bloodbrain barrier (Takada and Otsuka, 2007) and Richard et al., 2009). Its concentration in organisms is among the lowest of all amino acids (Emadi et al., 2010) and it has relatively low tissue storage also Trp can be used for the feed additive which exerts the stress reducing effect in domestic animals (Swennen et al., 2007). Trp is considered as a precursor of serotonin [5-hydroxytryptamine (5-HT)]. Serotonin (aneurotransmitter) has many functions in the central nervous system to inhibit aggression and modulates stress response, including social and environmental adaptability (Martin et al., 2000). 


\section{Soltan and Hussein}

Melatonin is a metabolite in the serotonin pathway of tryptophan as an essential amino acid. Apart from being a structural component of all proteins it is a precursor for synthesis of two hormones, serotonin and melatonin. These hormones generally act in the classic check and balance mode with serotonin predominating during periods of activity (usually daylight) and melatonin predominating during periods of rest (usually nighttime). Tryptophan is an essential amino acid for chickens that is necessary for maximum growth and feed efficiency and it is a precursor of serotonin. Some previous studies have shown that dietary tryptophan levels could regulate feed intake, behavior, growth, immunity, protein synthesis and intestinal integrity of chicken (Corzo et al., 2005 and Shen et al., 2012a, b). Castro et al. (2000) observed that different levels of total tryptophan (0.18 to $0.24 \%)$ supplementation on diet of broilers from 1 to 21 days of age effect on weight gain and feed conversion ratio, estimating the requirements on 0.212 and $0.208 \%$ of total tryptophan. (Rosa and Pesti 2001, Fraiha 2002 and Tabiri et al., 2002), reported that the level of $0.25 \%$ tryptophan supplementation is necessary to maximize feed intake. Duarte et al. (2013) noted that the level of $0.23 \%$ of digestible tryptophan numerically improves feed conversion.

Also, Hsia et al. (2005) indicated that showed that the feed intake, performance and were influenced by tryptophan content in the diet between $0.198 \%$ significantly better than in the $0.167 \%$. Emmanuel et al. (2016) indicated that Chicks fed $0.24 \%$ dietary tryptophan gave the highest final body weight, average daily gain and better feed conversion ratio. (Ghosh et al., 2007 and Mollaoglu et al., 2007) observed that dietary supplementation of $0.27 \%$ of tryptophan under the high stocking density conditions, indicates that increased activities of GPT in plasma. Emadi et al. (2010) showed that the diet with increase of dietary Trp levels ( 0.10 to 0.20$)$ had significantly improved albumin, total protein, glucose and decreased aspartate amino-transferase, triglyceride and cholesterol of broiler at 49 day of age. How ever, Wong et al. (2014) reported that increased dietary tryptophan significantly $(\mathrm{P} \leq 0.01)$ increasing total cholesterol in the plasma. The present study conducted to investigate the effect of feeding different levels of tryptophan supplementation on the performance traits and some plasma blood constituents and economical efficiency of Sinai Bedouin chick's during growth period.

\section{MATERIALS AND METHODS}

This experiment was conducted in the Poultry Research Farm and the Poultry Nutrition Laboratory, Faculty of Agriculture, Minufia University, Shebin El-kom, Egypt. The aim of this experiment was to study the effect of different levels of tryptophan on growth performance, blood plasma constituents and economic efficiency of Sinai Bedouin chicks under local environmental conditions.

One hundred and twenty, unsexed Sinai Bedouin chicks, one day old were used in the experiment. Flock history: Sinai Bedouin fowl is one of the Egyptian local strains. Chickens were characterized by laying fewer eggs which were smaller in weight. The first study was conducted by Arad et al. (1975) during the occupation of Sinai by Israel. This breed was compared to F1 crossbred from leghorn males X Sinai females. Additional information has been gathered concerning egg shell characteristic of the Sinai breed in comparison with White Leghorn as reported by Arad and Marder (1982 a). They concluded that Sinai egg shell is thicker and stronger than that of the Leghorn. The result of Arad and Marder (1982 b) reported that Sinai breed was more resistant to the extreme conditions of desert environment. Later on, Soltan et al. (1985) gave an economical study for this breed.

Soltan and El-Nady (1986) found that average body weights were 357.6, 486.6 and 711.6.9 for Sinai selected at 12, 16 and 20 weeks. Corresponding values for control line were $347.7,510$ and $717.7 \mathrm{~g}$, in the same respective order. They added that viability of Sinai selected chickens were 94.2, 92.9, 92.5, 89.3, 83.6 and $83.3 \%$ at $8-12,12-16,16-20$, hatch -12 , hatch-16 and hatch-20 weeks of age, respectively. Recently, Soltan et al. (2009) recorded BWSM of 1300.2 and $1123.0 \mathrm{~g}$ in the selected and control lines and they observed that the difference between both lines was not significant.

Chicks were wing banded, weighed and distributed into four dietary treatments of 30 chicks and divided into 3 replicates of 10 chicks. Chicks were reared in pens with litter (wheat straw) from 1 day to 16 weeks old of age under similar managerial and hygienic conditions. Feed and water were provided ad libitum during the experimental period. Artificial light was used to provide 24- hours / day photo period. The first group $\left(\mathrm{T}_{1}\right.$, control basal diet content normal level of tryptophan supplementation, $\mathrm{T}_{2}, \mathrm{~T}_{3}$ and $\mathrm{T}_{4}$ contented the supplementation of tryptophan at the levels of $0.20,0.25$ and $0.30 \%$, respectively. The diets (Table 1) with isocaloric and isonitrogenios based on National Research Council, NRC (1994) recommendation. 
Table (1). Composition and chemical analysis of the experimental Sinai Bedouin chick's diets fed during the experimental periods.

\begin{tabular}{|c|c|c|c|c|}
\hline \multirow[b]{2}{*}{ Ingredient } & \multicolumn{4}{|c|}{ Dietary treatment } \\
\hline & $\begin{array}{c}\mathrm{T}_{1} \\
\text { Control }\end{array}$ & $\mathrm{T}_{2}$ & $\mathrm{~T}_{3}$ & $\mathrm{~T}_{4}$ \\
\hline Ground yellow corn $(8.9 \%)$ & 67.87 & 67.85 & 67.83 & 67.82 \\
\hline Soybean meal (44\%) & 20.87 & 20.85 & 20.84 & 20.82 \\
\hline Wheat bran & 7.76 & 7.75 & 7.73 & 7.71 \\
\hline Limestone, ground & 1.87 & 1.87 & 1.87 & 1.87 \\
\hline Di-calcium phosphate & 0.82 & 0.82 & 0.82 & 0.82 \\
\hline Vitamin and mineral mixture ${ }^{2}$ & 0.30 & 0.30 & 0.30 & 0.30 \\
\hline L- Lysine & 0.10 & 0.10 & 0.10 & 0.10 \\
\hline DL-methionine ${ }^{3}$ & 0.14 & 0.14 & 0.14 & 0.14 \\
\hline L- Tryptophan ${ }^{4}$ & - & 0.05 & 0.10 & 0.15 \\
\hline Sodium chloride (salt) & 0.27 & 0.25 & 0.25 & 0.25 \\
\hline Total & 100 & 100 & 100 & 100 \\
\hline \multicolumn{5}{|l|}{ Calculated values ${ }^{5}$ : } \\
\hline Crude protein , $\%$ & 16.36 & 16.36 & 16.36 & 16.36 \\
\hline $\mathrm{ME}, \mathrm{Kcal} / \mathrm{kg}$ diet & 2841 & 2841 & 2841 & 2841 \\
\hline $\mathrm{C} / \mathrm{P}$ ratio & 173 & 173 & 173 & 173 \\
\hline Lysine, $\%$ & 0.84 & 0.84 & 0.84 & 0.84 \\
\hline Methionine, $\%$ & 0.33 & 0.33 & 0.33 & 0.33 \\
\hline Tryptophan,\% & 0.15 & 0.20 & 0.25 & 0.30 \\
\hline Calcium, $\%$ & 0.92 & 0.92 & 0.92 & 0.92 \\
\hline Av. phosphorus ,\% & 0.47 & 0.47 & 0.47 & 0.47 \\
\hline
\end{tabular}

${ }^{1} \mathrm{T1}$; control; with supplementation normal tryptophan level, T2; control $+0.20 \%$ Trp.; T3, control $+0.25 \% \operatorname{Trp}$. andT4, control $+0.30 \%$ Trp.

${ }^{2}$ Vitamin and Mineral mixture at 0.30\%of the diet supplies the following per kilogram of the diet: vit.A, 1200 IU; Vit.D3, $2500 \mathrm{IU}$; Vit. E, $10 \mathrm{mg}$; Vit.K3, 3mg; Vit.B1, Img; Vit.B2, 4mg; pant Nicotinic acid, $10 \mathrm{mg}$; Nicotinic acid, $20 \mathrm{mg}$; Folic- acid, $1 \mathrm{mg}$; Biotin, $0.05 \mathrm{mg}$; Niacin, $40 \mathrm{mg}$; Vit.B6, $3 \mathrm{mg}$, Vit. B12, $20 \mathrm{mcg}$; Choline Chloride, $400 \mathrm{mg}$; $\mathrm{Mn}, 62 \mathrm{mg}$; $\mathrm{Fe}$, $44 \mathrm{mg}$; Zn, $56 \mathrm{mg}$; I, $1 \mathrm{mg}$; $\mathrm{Cu}, 5 \mathrm{mg}$ and Se, $0.01 \mathrm{mg}$.

${ }^{3}$ Dl-Methionine: $98 \%$ feed grade (contains $98 \%$ methionine).

${ }^{4}$ L-Tryptophan; $98 \%$ feed grade (contains $98 \%$ tryptophan).

${ }^{5}$ Calculated according to NRC (1994).

Body weights and Feed consumption of the chicks were recorded weekly. Body weight gain, feed conversion and economical efficiency were calculated. Performance index (PI) was calculated according to North (1984) as follow: PI=live body weight $(\mathrm{kg}) \times 100 /$ feed conversion. Growth rates (GR) in different ages were calculated according to Brody (1945) as follow:

$$
\mathrm{GR} \%=\{(\mathrm{W} 2-\mathrm{W} 1) / 0.5(\mathrm{~W} 2+\mathrm{W} 1)\} \times 100
$$
Where: Weight $1=$ first weight
Weight $2=$ second weight

At the end of the experiment period, blood samples were collected from wing vein of six chicks from each treatment were randomly chosen. Blood samples were collected in heparinized tubes and plasma was separated by centrifugation at $3500 \mathrm{rpm}$ for $15 \mathrm{~min}$ and frozen at $-20^{\circ} \mathrm{c}$ for the determination of glucose, glucose, total protein, albumin, and transaminases (ALT and AST) which were calorimetrically determined using commercial kits. The globulin values were obtained by subtracting the values of albumin from the corresponding values of total protein (Coles, 1974); also albumin / globulin ratio (A/G ratio) was calculated. Proximate analysis of representative samples from experimental diets was determined according to the methods of (AOAC, 2011).

The economic efficiency was calculated from the input - output analysis (Heady and Jensen, 1954) assuming that other head costs were constant, as follows: [(price of $\mathrm{kg}$ weight gain-feed cost $/ \mathrm{kg}$ gain)/ feed cost $/ \mathrm{kg}$ gain $\times 100$ ] under local conditions. Data were statistically analyzed by the completely randomized design using the statistical software of SPSS 11.0 (2011) program and the differences among means were determined using Duncan's multiple range test (Duncan 1955). Percentages were transformed to the corresponding arcsine values before performing statistical analysis. 
The following statistical model was applied:

$\mathrm{Y}_{\mathrm{ij}}=\mu+\mathrm{T}_{\mathrm{i}}+\mathrm{e}_{\mathrm{ij}}$,

Where: $Y_{i j}=$ an observation, $\mu=$ Overall mean., $T_{i}=$ effect of treatment $(i=1,2,3,4)$ and $e_{i j}=$ experimental random error.

\section{RESULTS AND DISCUSSION}

Data presented in Table (2) showed that the different levels of dietary Tryptophan (Trp) had a significant on body weight and body weight gain of Sinai Bedouin chicks during $1-16$ weeks. It is clearly observed that the control group always had the lowest significantly BW and BWG throughout the experimental period. The birds fed diet contained $0.30 \%$ Trp recorded the heaviest BW and BWG (843.88 and 807.77g.) compare to other dietary treatments $\mathrm{T}_{2}, \mathrm{~T}_{3}$ and $\mathrm{T}_{1}$, control (BW: 803.13, 822.52 and 762.75; BWG: 766.58, 786.19 and $725.90 \mathrm{~g}$ ), respectively at 16 weeks of age. The current result was agreement with the results by (Emadi et al., 2010; Shen et al., 2012a, b and Patil et al., 2013) who, concluded that dietary tryptophan might have positive effects on body weight gain, feed intake of the broiler chickens. However, Edmonds and Baker (1987) and El- Gogary (2014) who, indicated that increasing tryptophan level in the diet did not affected live body Wight and body weight gain.

Table (2). Effect of supplemental Tryptophan (Trp.) on body weight and body weight gain of Sinai Bedouin chicks during the experimental periods (Mean $\pm \mathrm{SE})^{2}$.

\begin{tabular}{|c|c|c|c|c|}
\hline \multirow[b]{2}{*}{ Age weeks } & \multicolumn{4}{|c|}{ Dietary treatments $^{1}$} \\
\hline & $\begin{array}{c}\mathrm{T}_{1} \\
\text { Control }\end{array}$ & $\mathrm{T}_{2}$ & $\mathrm{~T}_{3}$ & $\mathrm{~T}_{4}$ \\
\hline & \multicolumn{4}{|c|}{ 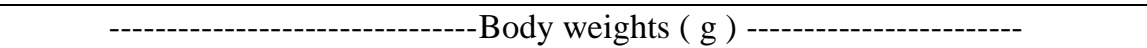 } \\
\hline One - day & $36.85 \pm 0.54$ & $36.55 \pm 0.48$ & $36.33 \pm 0.55$ & $36.11 \pm 0.47$ \\
\hline $4 \mathrm{Wk}$ & $157.65 \pm 6.33^{\mathrm{d}}$ & $162.29 \pm 10.11^{\mathrm{c}}$ & $169.36 \pm 4.25^{\mathrm{b}}$ & $170.58 \pm 19.90^{\mathrm{a}}$ \\
\hline $8 \mathrm{Wk}$ & $331.01 \pm 15.23^{\mathrm{d}}$ & $348.08 \pm 22.02^{\mathrm{c}}$ & $364.92 \pm 13.20^{\mathrm{b}}$ & $380.08 \pm 4.55^{\mathrm{a}}$ \\
\hline $12 \mathrm{Wk}$ & $498.02 \pm 6.50^{\mathrm{d}}$ & $521.25 \pm 5.41^{\mathrm{c}}$ & $539.25 \pm 6.66^{\mathrm{b}}$ & $560.08 \pm 4.32^{\mathrm{a}}$ \\
\hline \multirow[t]{2}{*}{$16 \mathrm{Wk}$} & $762.75 \pm 11.23^{\mathrm{d}}$ & $803.13 \pm 7.75^{\mathrm{c}}$ & $822.52 \pm 15.10^{\mathrm{b}}$ & $843.88 \pm 11.19^{\mathrm{a}}$ \\
\hline & \multicolumn{4}{|c|}{----------------------- Body weight gain ( g ) ---------------------------- } \\
\hline $0-4 \mathrm{Wk}$ & $120.80 \pm 7.55^{\mathrm{c}}$ & $125.74 \pm 6.53^{\mathrm{b}}$ & $133.03 \pm 7.11^{\mathrm{a}}$ & $134.47 \pm 7.92^{\mathrm{a}}$ \\
\hline $4-8 \mathrm{Wk}$ & $170.67 \pm 10.04^{\mathrm{d}}$ & $181.71 \pm 19.22^{\mathrm{c}}$ & $187.06 \pm 12.83^{\mathrm{b}}$ & $198.32 \pm 11.25^{\mathrm{a}}$ \\
\hline $8-12 \mathrm{Wk}$ & $172.39 \pm 3.22^{\mathrm{d}}$ & $185.33 \pm 6.56^{\mathrm{c}}$ & $191.33 \pm 4.26^{\mathrm{b}}$ & $202.35 \pm 7.19^{\mathrm{a}}$ \\
\hline $12-16 \mathrm{Wk}$ & $267.42 \pm 4.63^{\mathrm{d}}$ & $289.96 \pm 11.30^{\mathrm{c}}$ & $296.77 \pm 9.53^{\mathrm{b}}$ & $311.28 \pm 12.11^{\mathrm{a}}$ \\
\hline $0-16 \mathrm{Wk}$ & $725.90 \pm 7.02^{\mathrm{d}}$ & $766.58 \pm 6.91^{\mathrm{c}}$ & $786.19 \pm 5.44^{\mathrm{b}}$ & $807.77 \pm 7.11^{\mathrm{a}}$ \\
\hline
\end{tabular}

${ }^{I} \mathrm{Tl}$; control; with supplementation normal tryptophan level, T2; control $+0.20 \% \operatorname{Trp}$; T3, control + $0.25 \%$ Trp. andT4, control $+0.30 \%$ Trp.

${ }^{2}$ means \pm SE of 3 replicates / treatment.

${ }^{3} a, b, c$ and ....etc: means within the row with each different superscript are significantly different $(P \leq$ 0.05).

N.S: Non significant

Results in Table (3) showed that chicks fed supplemented diets significantly consumed more amount of feed compared to the chicks fed control diet with fed different levels of fiber during the growing periods (Table 3). The birds fed diet contained $0.30 \%$ Trp. recorded significantly $(\mathrm{P} \leq 0.05)$ the highest as compared to the control and other groups being 2408.54, 2250.34, 2317.34 and $2363.58 \mathrm{~g}$ for $\mathrm{T}_{4}, \mathrm{~T}_{1}, \mathrm{~T}_{2}$ and $\mathrm{T}_{3}$, respectively. While birds fed diet contained $0.30 \%$ Trp significantly $(\mathrm{P} \leq 0.05)$ recorded better feed conversion ratio (2.98) compared to the control (3.10). There was a trend that feed intake increased with increasing level of tryptophan by the results confirmed the pervious findings of several researches Harms and Russell (2000); Peganova and Eder (2003); Hsia et al.(2005) and Rostagno et al. (2005).

Also Corzo (2012) reported that Body weight gain, feed consumption, and feed conversion responses of Cobb 500 male broiler chicks fed increasing dietary ratios of Tryptophan: Lysine (19.5 and 19.7\% \%) from 0 to $18 \mathrm{~d}$ post hatch. ( Patil et al., 2013; Duarte, et al., 2013 and Wong et al., 2014) who found that supplementation tryptophan level of broiler diet improvement in feed conversion ratio of birds. 
Emmanuel et al. (2016) found that chicks fed $0.15 \%$ total dietary tryptophan had significantly higher $(\mathrm{p}<0.05)$ value for feed intake $(1,789.90 \mathrm{~g})$.

Table (3). Effect of supplemental Tryptophan (Trp.) on feed intake and feed conversion ratio Sinai Bedouin chicks during the experimental periods (Mean $\pm \mathrm{SE})^{2}$.

\begin{tabular}{|c|c|c|c|c|}
\hline \multirow{2}{*}{ Age (week) } & \multicolumn{4}{|c|}{ Dietary treatment $^{1}$} \\
\hline & $\begin{array}{c}\mathrm{T}_{1} \\
\text { Control }\end{array}$ & $\mathrm{T} 2$ & T3 & $\mathrm{T} 4$ \\
\hline & \multicolumn{4}{|c|}{ - } \\
\hline $0-4 \mathrm{Wk}$ & $291.13 \pm 3.25^{\mathrm{d}}$ & $296.75 \pm 2.98^{c}$ & $305.97 \pm 3.33^{\mathrm{b}}$ & $307.22 \pm 3.08^{\mathrm{a}}$ \\
\hline $4-8 \mathrm{Wk}$ & $443.74 \pm 2.12^{\mathrm{d}}$ & $466.99 \pm 3.96^{\mathrm{b}}$ & $443.26 \pm 2.85^{\mathrm{c}}$ & $483.90 \pm 4.47^{\mathrm{a}}$ \\
\hline $8-12 \mathrm{Wk}$ & $558.11 \pm 9.63^{\mathrm{d}}$ & $563.00 \pm 3.65^{\mathrm{c}}$ & $606.07 \pm 7.11^{\mathrm{b}}$ & $618.76 \pm 4.52^{\mathrm{a}}$ \\
\hline $12-16 \mathrm{Wk}$ & $957.36 \pm 11.23^{\mathrm{d}}$ & $990.60 \pm 9.81^{\mathrm{c}}$ & $1008.28 \pm 12.30^{\mathrm{a}}$ & $998.66 \pm 11.41^{\mathrm{b}}$ \\
\hline \multirow[t]{2}{*}{$0-16 \mathrm{Wk}$} & $2250.34 \pm 10.50^{\mathrm{d}}$ & $2317.34 \pm 12.39^{c}$ & $2363.58 \pm 11.58^{\mathrm{b}}$ & $2408.54 \pm 12.01^{\mathrm{a}}$ \\
\hline & \multicolumn{4}{|c|}{---------------feed Conversion, FC (g feed/g gain) ------------------- } \\
\hline $0-4 \mathrm{Wk}$ & $2.41 \pm 0.04^{\mathrm{a}}$ & $2.36 \pm 0.04^{\mathrm{b}}$ & $2.30 \pm 0.33^{\mathrm{b}}$ & $2.28 \pm 0.03^{\mathrm{a}}$ \\
\hline $4-8 \mathrm{Wk}$ & $2.60 \pm 0.05^{\mathrm{c}}$ & $2.57 \pm 0.05^{\mathrm{b}}$ & $2.53 \pm 0.05^{\mathrm{b}}$ & $2.44 \pm 0.03^{\mathrm{a}}$ \\
\hline $8-12 \mathrm{Wk}$ & $3.24 \pm 0.04^{\mathrm{c}}$ & $3.03 \pm 0.05^{\mathrm{a}}$ & $3.17 \pm 0.01^{\mathrm{b}}$ & $3.05 \pm 0.03^{\mathrm{a}}$ \\
\hline $12-16 \mathrm{Wk}$ & $3.58 \pm 0.03^{\mathrm{c}}$ & $3.42 \pm 0.04^{\mathrm{c}}$ & $3.39 \pm 0.06^{\mathrm{b}}$ & $3.21 \pm 0.02^{\mathrm{a}}$ \\
\hline $0-16 \mathrm{Wk}$ & $3.10 \pm 0.02^{\mathrm{d}}$ & $3.02 \pm 0.02^{\mathrm{c}}$ & $3.01 \pm 0.01^{\mathrm{b}}$ & $2.98 \pm 0.03^{\mathrm{a}}$ \\
\hline \multicolumn{5}{|c|}{$\begin{array}{l}1 \text { T1; control; with supplementation normal tryptophan level, T2; control }+0.20 \% \text { Trp.; T3, control }+0.25 \% \text { Trp. } \\
\text { andT4, control }+0.30 \% \text { Trp. } \\
{ }^{2} \text { means } \pm \text { SE of } 3 \text { replicates } / \text { treatment. } \\
{ }^{3} a, b, c \text { and ....etc: means within the row with each different superscript are significantly different }(P \leq 0.05) \text {. } \\
\text { N.S: Non significant }\end{array}$} \\
\hline
\end{tabular}

On the other hands, Rosa et al. (2001) and El- Gogary (2014) showed that increasing L- tryptophan level in the diet did not affected feed conversion ratio. However, feed intake decreased significantly with L- tryptophan at 0.75 and $1.0 \mathrm{~g} / \mathrm{kg}$ diet. Results on performance index (P.I.) and growth rate (G.R)

Table (4) showed significant differences $(\mathrm{P} \leq 0.05)$ as influenced by dietary different levels of tryptophan to Sinai Bedouin chicks at 8 and 16 weeks. This effect could be due to the function of tryptophan as a precursor of the neurotransmitter serotonin. It is well know that serotonin, feed consumption of animals Shea-Moore et al. (1996) and Peganova and Eder (2003).

Table (4). Effect of supplemental Tryptophan (Trp.) on performance index (PI.) and growth rate (GR.)of Sinai Bedouin chicks during the experimental periods $(\mathrm{Mean} \pm \mathrm{SE})^{2}$.

\begin{tabular}{|c|c|c|c|c|c|}
\hline \multirow[b]{2}{*}{ Age (week) } & \multicolumn{5}{|c|}{ Dietary treatments $^{1}$} \\
\hline & $\begin{array}{c}\mathrm{T}_{1} \\
\text { Control }\end{array}$ & $\mathrm{T}_{2}$ & $\mathrm{~T}_{3}$ & $\mathrm{~T}_{4}$ & Sig \\
\hline \multirow{4}{*}{$\begin{array}{l}8 \mathrm{wk} . \\
16 \mathrm{Wk} .\end{array}$} & \multicolumn{5}{|c|}{ 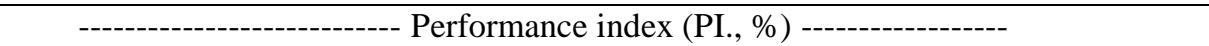 } \\
\hline & $65.60 \pm 1.16^{\mathrm{c}}$ & $70.72 \pm 1.64^{\mathrm{ab}}$ & $73.95 \pm 2.35^{b}$ & $81.33 \pm 1.08^{\mathrm{a}}$ & $*$ \\
\hline & $74.75 \pm 2.22^{\mathrm{d}}$ & $84.80 \pm 3.68^{c}$ & $87.82 \pm 1.34^{\mathrm{b}}$ & $95.81 \pm 1.12^{\mathrm{a}}$ & $*$ \\
\hline & & - Growth rat & .\% ) ----------. & --------- & \\
\hline $8 \mathrm{Wk}$. & $46.22 \pm 0.13^{\mathrm{bc}}$ & $49.19 \pm 1.02^{\mathrm{c}}$ & $51.94 \pm 0.68^{\mathrm{b}}$ & $55.00 \pm 0.60^{\mathrm{a}}$ & $*$ \\
\hline $16 \mathrm{Wk}$. & $72.16 \pm 1.98^{\mathrm{d}}$ & $78.78 \pm 2.20^{\mathrm{c}}$ & $82.50 \pm 3.12^{b}$ & $86.39 \pm 1.56^{\mathrm{a}}$ & $*$ \\
\hline \multicolumn{6}{|c|}{$\begin{array}{l}{ }^{1} \mathrm{~T} 1 \text {; control; with supplementation normal tryptophan level, T2; control }+0.20 \% \text { Trp.; T3, control }+0.25 \% \text { Trp. } \\
\text { andT4, control }+0.30 \% \text { Trp. } \\
{ }^{2} \text { means } \pm \text { SE of } 3 \text { replicates / treatment. }\end{array}$} \\
\hline
\end{tabular}




\section{Soltan and Hussein}

Results of blood constituents as affected by different levels of tryptophan are summarized in Table (5). It is clear that chicks fed diet containing tryptophan at level $0.30 \%\left(\mathrm{~T}_{4}\right)$ had the significantly higher glucose, total protein and albumin concentration, and lower total lipids, and total cholesterol comparing with those fed the control diet. However, here is no significant difference among treatments in blood components representing liver function (as measured by ALT and AST).

Table (5). Effect of supplemental Tryptophan (Trp.) on some blood plasma constituents of Sinai Bedouin chicks $(\text { Mean } \pm \mathrm{SE})^{2}$.

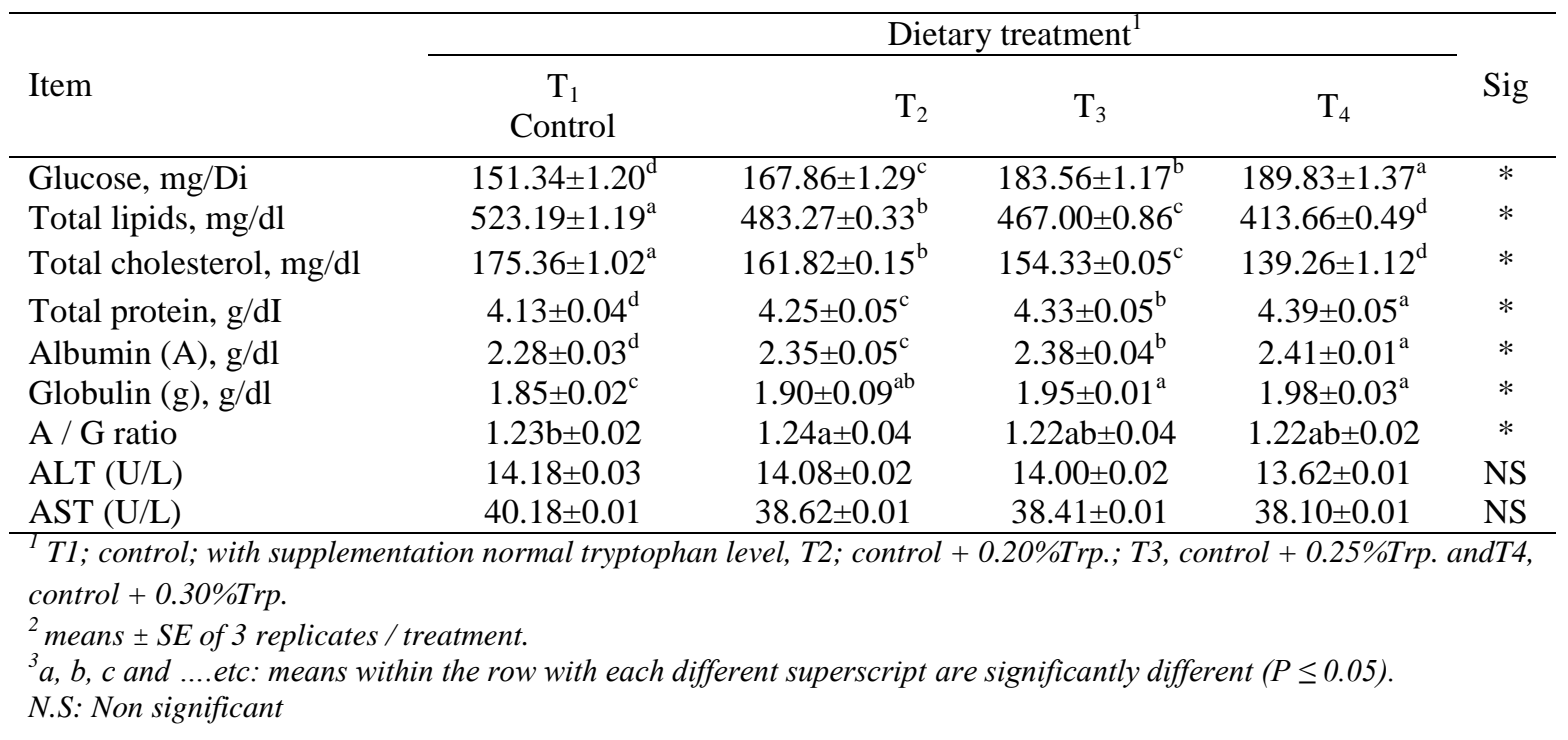

The obtained results confirmed the previous findings of several researches (Ghosh et al., 2007; Mollaoglu et al., 2007 and Emadi et al., 2010).Wong et al. (2014) observed that tryptophan supplementation had positive effects on concentration of albumin, total protein, and glucose; however, dietary tryptophan had decreased of cholesterol and triglyceride of the broiler chickens and no effects on serum aspartate amino-transferase (AST) and alkaline phosphatase (ALT) at 27 to 49 day of age. ElGogary (2014) showed that increasing L- tryptophan level in the diet at 0.75 and $1.0 \mathrm{~g} / \mathrm{kg}$ had no effects on plasma total protein and glucose. However plasma cholesterol levels decreased significantly $(\mathrm{P} \leq 0.05)$ with L- tryptophan Supplementation and lowest levels occurred at $0.25 \mathrm{~g} / \mathrm{kg}$.

Birds with higher body weight were observed to have a higher concentration of blood plasma total protein when compared with the lighter broilers, possibly associated with higher demand for lean tissue maintenance and turn over (Corzo et al., 2005). The economic efficiency of the experimental treatments (Table 6) indicates that the highest economic and relative economic efficiency values were obtained with the diet supplemented with graded levels of tryptophan. It may be due to better feed conversion of birds received the experimental diets. In conclusion, under our experimental condition, supplementing tryptophan to Sinai Bedouin chick's (during growth period) diet had a positive effect on growth performance and some blood constituents, especially addition $0.30 \%$ tryptophan could be recommended for improving Sinai Bedouin chick's health and economic efficiency 
Table (6). The economic efficiency of the experimental diets as effected by different levels of tryptophan (Trp) supplementation.

\begin{tabular}{|c|c|c|c|c|}
\hline \multirow[b]{2}{*}{ Item } & \multicolumn{4}{|c|}{ Dietary treatment $^{1}$} \\
\hline & $\begin{array}{c}\mathrm{T}_{1} \\
\text { Control }\end{array}$ & $\mathrm{T}_{2}$ & $\mathrm{~T}_{3}$ & $\mathrm{~T}_{4}$ \\
\hline Initial body weight gain, $(\mathrm{g})$ & 36.85 & 36.55 & 36.33 & 36.11 \\
\hline Final body weight, $(\mathrm{kg})$ & 763 & 803 & 823 & 844 \\
\hline Body weight gain. ( $\mathrm{kg}$ ) & 726 & 766 & 787 & 808 \\
\hline Total revenue (L.E) ${ }^{2}$ & 18.15 & 19.15 & 19.67 & 20.20 \\
\hline Feed intake ( $\mathrm{Kg}$ ) & 2.25 & 2.32 & 2.36 & 2.41 \\
\hline Price of $\mathrm{Kg}$ feed ( L.E) & 6.20 & 6.21 & 6.23 & 6.24 \\
\hline Feed cost ( L.E) & 13.95 & 14.41 & 14.70 & 15.04 \\
\hline Net revenue $(\mathrm{L} . \mathrm{E})^{3}$ & 4.20 & 4.74 & 4.97 & 5.16 \\
\hline Economic efficiency, $(\%)^{4}$ & 30.11 & 32.89 & 33.80 & 34.31 \\
\hline Economic efficiency relative $(\%)$ & 100 & 109 & 112 & 114 \\
\hline $\begin{array}{l}{ }^{T} \text { T1; control; with supplementation no } \\
\text { T3, control }+0.25 \% \text { Trp. andT4, contr } \\
{ }^{2} \text { Total revenue }=\text { Body weight gain }(K \\
- \text { Assuming the price of one }- \text { Kg live } b \\
{ }^{3} \text { Net revenue }=\text { Total revenue }- \text { Feed } \\
{ }^{4} \text { Economical efficiency }=(\text { Net revenu }\end{array}$ & $\begin{array}{l}\text { T2; cont } \\
\text { live bod } \\
\text { ccording }\end{array}$ & $\operatorname{Trp} . ;$ & & \\
\hline
\end{tabular}

\section{REFERENCES}

Arad, Z. and J. Marder (1982 a). Comparison of the productive performances of the Sinai Bedouin fowl, the White Leghorn and their crossbred: Study under laboratory conditions. Bri. Poult. Sci. 23: 329 332

Arad, Z. and J. Marder (1982 b). Comparison of the productive performances of the Sinai Bedouin fowl, the White Leghorn and their crossbred: Study under natural desert conditions. Bri. Poult. Sci. 23: 333 $-338$

Arad, Z., E. Moskovits and J. Marder (1975). A preliminary study of egg production and heat tolerance in a new breed of fowl (Laghorn x Bedouin). Poult. Sci. 54 : 780 - 783.

AOAC., (2011). Official methods of analytical chemists.18th ed. Association of Official Analytical Chemists, Arlington, VA, USA.

Brody, S. (1945). Bioenergetics and growth. Reynold Pub. Crop., New York.

Castro, A.J., P.C. Gomes and J.M.R. Pupa(2000). Exigência de triptofano para frangos de corte de 1 a a21 dias de idade. Revista Brasileira de Zootecnia, v.29, n.6, p.1743-1749.

Corzo, A., M.T. Kidd, J.P. Thaxton and B.J. Kerr (2005). Dietary tryptophan effects on growth and stress responses of male broiler chicks. Br. Poult. Sci., 4: 478-484.

Coles, E. H. (1974). Veterinary clinical pathology. PP. 211-213, W.B. Saunders, Company, Philadalphia, London, Toronto.

Corzo, A. (2012). Determination of the arginine, tryptophan, and glycine ideal-protein ratios in highyield broiler chicks. J. Appl. Poult. Res. 21 :79-87.

Duarte, K. F., M. J. Otto, S. F. Rosemeire, S. Jefferson Costa, M. P. Maíra, A. G. Edivaldo, B. M. Andrea and L. Carlos (2013). Digestible tryptophan requirements for broilers from 22 to 42 days old. Revista Brasileira de Zootecnia, v.42, n.10, p.728-733.

Duncan, D. B. (1955). Multiple ranges and multiple F test. Biometrics, 11:1-42.

El-Gogary, M.R. and M.M. Azzam (2014). Effect of dietary tryptophan levels and stocking density during the growing - finishing phase on broiler performance and immunity. Asian Journal of Animal and Veterinary Advances, 9: 568-577. 


\section{Soltan and Hussein}

Edmonds M. S. and D. H. Baker (1987). Comparative effects of individual amino acid excesses when added to a corn-soybean meal diet: effects on growth and dietary choice in the chick. Journal of Animal Science, v.65, p.699-705.

Emadi, M., Kaveh, K., Bejo, M.H., Ideris, A., Jahanshiri, F. and R.A. Alimon (2010). Dietary tryptophan effects on growth performance and blood parameters in broiler chicks. Journal of Animal and Veterinary Advances, 9: 700-704.

Emmanuel O., Ogundipe S. O., G. S., Bawa and P. A. Onimisi (2016). Evaluation of optimum dietary tryptophan requirement for broiler chicks reared in the cold season under tropical environment. J. Vet. Sci. Technol, Volume 7 Issue 7(Suppl): 14-16.

Esonu, B. O. (2006). Animal nutrition and feeding: A functional approach. Second edition, Rukzeal \& Ruksons associates memory press, Owerri, Imo State.

Fraiha, M., (2002). Atualização em nutrição protéica para frangos de corte, Available at: . Accessed on: Nov. 20.

Ghosh G., De K. S. Maity, D . Bandyopadhyay, S. Bhattacharya, RJ. Reiter and Bandyopadhyay (2007). Melatonin protects against oxidative damage and restores expression of GLUT4 gene in the hyperthyroid rat heart.J PinealRes.42:71-82.

Harms, R.H. and G.B. Russell (2000). Evaluation on tryptophan requirement of the commercial layer by using a corn-soybean meal based diet. Poult. Sci., 79: 740-741.

Heady, E. O. and H. R. Jensen (1954). Farm Management Economics. Prentice-Hall Inc. Englewood Cliffs, N. J., USA.

Hsia, L. C. J. H. Hsu and C. T. Liao (2005). The Effect of Varying Levels of Tryptophan on Growth Performance and Carcass Characteristics of Growing and Finishing Broilers. (Asian-Aust. J. Anim. Sci. Vol 18, No. 2: 230-234).

Martin, C.L., M. Duclos, S. Aguerre, P. Mormede, G. Manier and F. Chaouloff (2000). Corticotropic and serotonergic responses to acute stress with/without prior exercise training in different rat strains. Acta Physiologica Scandinavica, 168: 421-430.

Mollaoglu H, T. Topal, M. Ozler,B. Uysal,RJ. Reiter, A. Korkmaz and S. Oter (2007). Antioxidant effects of melatonin in rats during chronic exposure to hyperbar.J Pineal Res.42:50-54.

North, M.O. (1984). Commercial chicken production manual.3rd Ed., The AVI Publishing Co. Inc., West-port, Connecticut, U.S.A.

NRC. (1994). Nutrient Requirements of Poultry. 9th ed. National Academy Press, Washington, DC.

Oluyemi, J. A. and F. A. Roberts (2007). Poultry production in warm wet climates. Spectrum books Limited, Ibadan.

Patil, R. J., J. S. Tyagi, M. Sirajudeen, R,Singh,R. R. Moudga and J. Mohan (2013). Effect of dietary melatonin and L- tryptophan on growth performance and immune responses of broiler chicken under experimental aflatoxicosis. Iranian Journal of Applied Animal Science, 3(1), 139-144.

Peganova, S. and K. Eder (2003). Interactions of various supplies of isoleucine, valine, leucine and tryptophan on the performance of laying hens. Poult. Sci., 82: 100-105.

Richard, D. M., M. A. Dawes, C. W. Mathias, A. Acheson, N. Hill-Kapturczak and D. M. Dougherty (2009). L-Tryptophan: Basic Metabolic Functions, Behavioral Research and Therapeutic Indications. International journal of tryptophan.

Rostagno, H. S., L. F. T. Albino, J. L. Donzele, P.C. Goms, A. S. Ferreira, A. F. Oliveira and D. C. Lopes (2005). Tabelas brasileiras para aves e suínos: composição de alimentos e exigências nutricionais. 2.ed. Viçosa, MG: UFV, Departamento de Zootecnia, 186p.

Rosa A. and GM. Pesti (2001). Estimation of the tryptophan requirement of chickens for maximum body weight gain and feed efficiency. J Appl Poult Res.10:135-140.

Shea-Moore M.M, O.P. Thomas and J.A. Mench (1996). Decreases in aggression in tryptophansupplemented broiler breeder males are not due to increases in blood niacin levels. Poult Sci.1996; 75:370-374.doi: 10.3382/ps.0750370. 
Shen, Y.B., G. Voilqué, J.D.. Kim, J. Odle and S.W. Kim (2012a). Effects of increasing tryptophan intake on growth and physiological changes in nursery pigs. J. Anim. Sci., 90:2264-2275. doi: 10.2527/jas.2011-4203.

Shen YB, G. Voilqué, JD. Kim, J. Odle and SW Kim(2012b). Dietary L-tryptophan supplementation with reduced large neutral amino acids enhances feed efficiency and decreases stress hormone secretion in nursery pigs under social-mixing stress. J Nutr.142:1540-1546. doi: 10.3945/jn.112.163824.

Soltan, M.E. and M.M. El-Nady (1986). Studies on the possibility of improvement of body weight, growth rate and viability in Bedouin fowl. J. Conf. Egypt. Soc. Of Animal. Prod.

Soltan, M.E.; M.M. El-Nady; B.M. Ahmed, and A.M. Abou-Ashour (1985). Studies on the productive performance of Sinai Bedouin fowl. Minoufiya. J. Agric. Res. 10 (4): 2147 - 2168.

Soltan, M.E., S. Abed El-Rahman, F.H. Abdou and Rasha, H., Ashour (2009). Direct selection response for feed efficiency of egg production. Mimufiya J. Agric. Res. Vol. 34, 3: $1011-1025$.

SPSS. (2011). SPSS 11.0 for Windows. SPSS Inc., Chicago. Standardization administration of china. 2005. National feed Industry Standards for Enzyme Assays in China.

Swennen Q., E. Decuypere and J. Buyse (2007). Implications of dietary macronutrients for growth and metabolism in broiler chickens. World Poultry Science Journal. 63 (4): 541 -556.

Tabiri, H. Y., K. Sato, K. Takahashi, M. Toyomizu and Y. Akiba (2002). Effects of heat stress and dietary tryptophan on performance and plasma amino acid concentrations of broiler chickens. Asian-Aust. J. Anim. Sci. 15(2):247-253.

Takada, R. and M. Otsuka (2007). Effects of feeding high tryptophan GM-rice on growth performance of chickens. International Journal of Poultry Science 6(7): 524-526.

Toride, Y. (2004). Lysine and other amino acids for feed: production and contribution to protein utilization in animal feeding. In FAO, Ed. Protein sources for the animal feed industry. Rome:, FAO, pp. 161 - 166. www. fao.org/3/a y5019e.pdf.

Wong Bo, Zhizhi Min, Jianmin Yuan, Bingkun Zhang and Yuming GUO (2014). Effects of dietary tryptophan and stocking density on the performance, meat quality, and metabolic status of broilers. Journal of Animal Science and Biotechnology.5:44.

Warnick, R. E. and J. O. Anderson (1968). Limiting essential amino acids in soybean meal for growing chickens and the effects of heat upon availability of the essential amino acids. Poultry Science, v.47, p.281-287. 
تأثير اضافة مستويات مختلفة من التربتوفان فى علائق كتاكيت سينا البدو على الأداء الإنتاجى وبعض صفات الام خلال فترة النمو

\author{
محمث السيد سلطان و إيمان عاشور محم حسين \\ قسم إنتاج الدواجن - كلية النزراعة - جامعة المنوفية - شبين الكوم - مصر فين
}

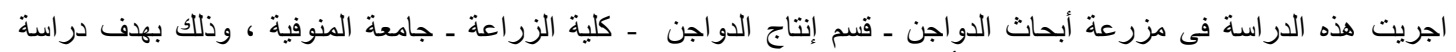

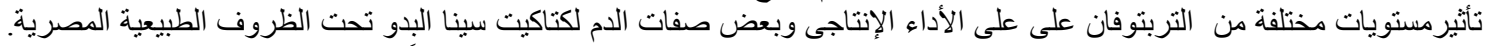

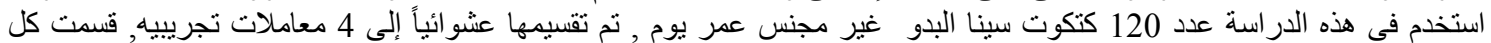

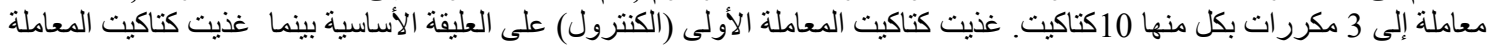

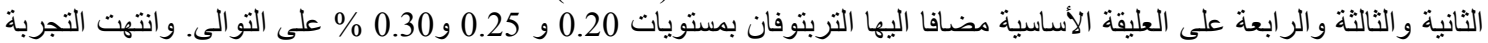

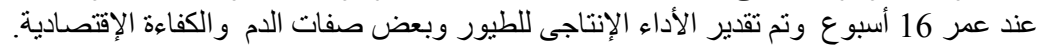

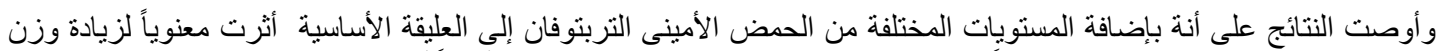

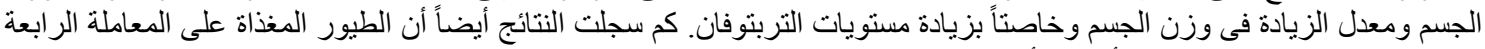

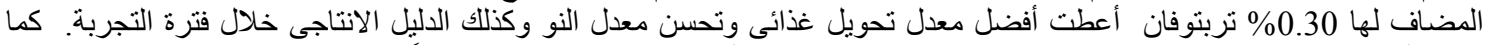

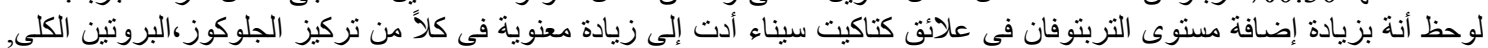

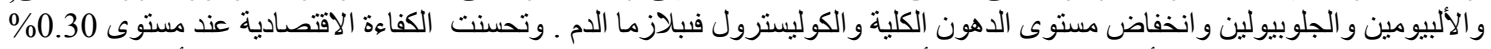

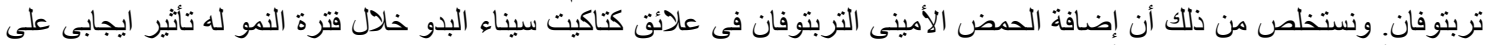

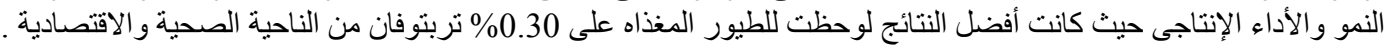

